TITLE:

\title{
Small-for-size syndrome in living donor liver transplantation
}

$\operatorname{AUTHOR}(S)$ :

Yagi, Shintaro; Uemoto, Shinji

\section{CITATION:}

Yagi, Shintaro ... [et al]. Small-for-size syndrome in living donor liver transplantation. Hepatobiliary \& Pancreatic Diseases International 2012, 11(6): 570-576

ISSUE DATE:

2012-12

URL:

http://hdl.handle.net/2433/169675

\section{RIGHT:}

(C) 2012 The Editorial Board of Hepatobiliary \& Pancreatic Diseases International. Published by Elsevier (Singapore) Pte Ltd.; This is not the published version. Please cite only the published version.; この論文は出版社版でありません。引用の際には出版社版 をご確認ご利用ください。 
Manuscript Type: Review article

Title: Small-for-size syndrome in living-donor liver transplantation

Running Title: SFSS in LDLT

Author: Shintaro Yagi, Shinji Uemoto

City: Kyoto, Japan

Author Affiliation: Department of Hepatobiliary, Pancreas and Transplant Surgery,

Kyoto University Graduate School of Medicine, 54 Kawara-cho, Shogoin, Sakyo-ku,

Kyoto City, 606-8507, Japan (Shintaro Yagi and Shinji Uemoto)

Corresponding Author: Shintaro Yagi M.D., Ph.D. Department of Hepatobiliary,

Pancreas and Transplant Surgery, Kyoto University, 54 Kawara-cho, Shogoin, Sakyo-ku,

Kyoto city, Kyoto prefecture, Japan 606-8507, Phone: +81-75-751-4323, Fax:

+81-75-751-4348, E-mail: shintaro@kuhp.kyoto-u.ac.jp

Funding: None

Ethical approval: Not needed

Competing interest: No benefits in any form have been received or will be received from a commercial party related directly or indirectly to the subject of this article. 


\section{Abstract}

When the graft volume is too small to satisfy the recipient's metabolic demand ("small-for-size graft": SFSG), the recipient may thus experience "small-for-size syndrome" (SFSS). Because the occurrence of SFSS is determined by not only the liver graft volume but also a combination of multiple negative factors, the definitions of SFSG and SFSS are different in each institute and at each time.

In the clinical setting, surgical inflow modulation and maximizing the graft outflow are keys to overcoming SFSS. Accordingly, relatively smaller-sized grafts can be used with surgical modification and pharmacological manipulation targeting portal circulation and liver graft quality. Therefore, the focus of the SFSG issue is now shifting from how to obtain a larger graft from the living donor to how to manage the use of a smaller graft to save the recipient, considering donor safety to be a priority. 


\section{Introduction}

In the last 20 years, the indications for living-donor liver transplantation (LDLT) have been successfully expanded from pediatric to adult cases. However, the use of grafts smaller than the native liver is unavoidable in cases of LDLT performed on adults. When the graft volume is too small to satisfy the recipient's metabolic demand ("small-for-size graft": SFSG), the recipient may thus experience "small-for-size syndrome" (SFSS). "SFSS" is characterized clinically by a combination of prolonged functional cholestasis, intractable ascites, and delayed functional recovery of both prothrombin time and encephalopathy (1-3). To avoid SFSG, the use of a larger-sized graft, such as the right lobe graft, is the standard strategy for adult-to-adult LDLT (4-7). However, although a right-lobe LDLT can provide an adequate graft size to meet the metabolic demands of most adult recipients, "SFSS" can be observed not only in "SFSG" recipients but also in larger-sized graft recipients (8-10). Therefore, the occurrence of SFSS is determined by not only the liver graft volume but also a combination of multiple negative factors.

However, the procurement of a liver graft of greater volume imposes a greater risk on the donor because the remaining portion of the liver in the donor is smaller. Accordingly, the 
criteria for SFSG in adult-to-adult LDLT have been revised recently at several institutes

$(2,11)$. In other words, a relatively smaller-sized graft, such as the left lobe, can be used in adults with surgical manipulations aimed at reducing the portal venous pressure (PVP) and flow (PVF) $(11,12)$. Therefore, the focus of the SFSG issue is now shifting from how to obtain a larger graft from the living donor to how to manage the use of a smaller graft to save the recipient, considering donor safety to be a priority.

\section{Definition}

Kiuchi et al. (1) defined "SFSG" as a $<0.8 \%$ graft-to-recipient body weight ratio (GRWR). They reported that the use of "SFSG" leads to "SFSS," including poor bile production, delayed synthetic function, prolonged cholestasis and intractable ascites, with subsequent septic complications and higher mortality. Sugawara et al. (13) suggested that a graft volume/standard liver volume ratio $(\mathrm{GV} / \mathrm{SLV})<40 \%$ was associated with decreased survival and the prolonged recovery of liver function. At present, some institutes have established criteria for graft selection with a lower GRWR than before:

GRWR $>0.8 \%(14,15)$ or GRWR $>0.6 \%$ in combination with PVP control (11); these criteria show that the definition of "SFSG" has become lower in LDLT. Although there 
has been no accepted definition of "SFSS" until now, several different definitions for

SFSS or liver graft dysfunction have been given $(3,16-18)$ (Table 1).

\section{Pathophysiology}

\section{Relative shortage of vital liver volume for life maintenance}

The first possibility of the pathogenesis of poor prognosis in SFSG is the relative shortage of hepatic parenchymal cells. Previous clinical analyses have suggested that a normal liver can tolerate a partial hepatectomy to $25-27 \%$ of the residual volume (19-21).

\section{Portal hypertension: shear stress}

The characteristic microscopic findings of SFSS, including hepatocyte ballooning and cholestasis, are thought to be due to microcirculatory disturbances (22). Many experimental and clinical studies (12,23-28) suggest that elevated PVP (shear stress) forms the central pathogenesis of SFSS. A persistent elevation of the PVP in the graft, which is attributable to hyperdynamic splanchnic circulation (29) and limited accommodation of the graft, causes sinusoidal endothelial cell injury (25) and the release of deleterious mediators (30), which ultimately lead to serious graft injury. Shear stress 
also leads to an imbalance in the expression of intragraft vasoregulatory genes, such as endothelin-1 and nitric oxide (31). Microcirculatory disorders in SFSG will eventually result in graft dysfunction (32).

\section{Arterial hypoperfusion}

The role of arterial hypoperfusion in SFSS is less well studied as it is secondary to portal hyperperfusion. Low hepatic artery flow is considered to be due to a homeostatic mechanism known as the hepatic arterial buffer response (33). In states of extreme portal hyperperfusion, such as those observed in SFSG, an exaggerated hepatic arterial buffer response may contribute to ischemic injury, ischemic cholangitis, and cholestasis.

\section{Intestinal mucosal injury}

We demonstrated that the intestinal mucosa was severely damaged with portal hypertension following SFSG liver transplantation in swine (26). Several experimental studies (34-39) have revealed that portal hypertension in liver cirrhosis can increase bacterial translocation by inducing congestion and edema of the intestine. Accordingly, bacterial translocation could be developed in an SFSG-transplanted recipient due to the elevation of mucosal permeability, which is compatible with the clinical aspect of a 
higher postoperative infection rate in SFSS (40).

\section{Liver regeneration}

After extensive hepatectomy or segmental liver transplantation with an SFSG, liver regeneration is essential for patient survival. Liver regeneration is a highly complex and organized process that has been shown to involve the actions of a number of cytokines and growth factors, such as hepatocyte growth factor (HGF) (41), transforming growth factor- $\alpha$ (42), epidermal growth factor (43), hepatocyte growth factor activator (HGFA) (44) and vascular endothelial growth factor (VEGF) (45). Shear stress is well defined as a putative trigger mechanism for liver regeneration (46-48). During the first week after a partial liver transplantation, the partial liver graft regenerates quickly, up to approximately 80-100\% compared with the standard liver volume (47). Ninomiya et al. (49) showed that SFSGs regenerated faster and were associated with significantly higher peripheral HGF levels one day after LDLT than non-SFSGs. Many previous studies have suggested that the elevation of PVF or shear stress induces liver regeneration and that insufficient PVF induces hepatic atrophy and liver failure (50-57). Portal hyperperfusion can promote liver regeneration only if it is limited to a certain extent. Hessheimer et al. 
(58) suggested that the liver graft requires PVF superior to its normal baseline value for liver regeneration and that a calibrated portocaval shunt (PCS) that maintains the PVF at twice its baseline value produces a favorable outcome after swine liver transplantation with a $30 \%$ SFSG.

\section{Clinical Factors influencing SFSS}

\section{Quality of the graft}

Factors regulating liver graft compliance would be the potential definition of the graft quality, such as donor age, steatosis, and ischemic injury. Other unknown factors may also precipitate SFSS.

\section{a. Ischemic injury}

Both warm (59) and cold ischemia (60) have been shown to impair regeneration after partial liver transplantation. The difference in the essential liver volume after the operation between an extended hepatectomy and partial liver transplantation may owe much to the existence of this issue.

\section{b. Steatosis}


A steatotic liver graft from a deceased donor with a longer cold ischemic time is well known to be associated with poor graft function and survival. A previous study revealed that steatotic liver grafts are related to the increased susceptibility to ischemia-reperfusion injury $(61,62)$, including impaired graft microcirculation and PVF, increased hepatocellular damage observed serologically and histologically, increased pro-inflammatory cytokine production, and decreased ATP concentration. However, in an LDLT setting with a shorter cold ischemic time compared with a deceased donor graft, Hayashi et al. (63) reported that early graft function after LDLT was similar in mild and moderate steatosis but that severe steatosis was significantly associated with poor graft function and survival. In any case, SFSS is determined by a combination of multiple negative factors, and steatotic liver grafts should be avoided if the graft volume is small.

\section{c. Donor age}

Moon et al. (64) have shown that an older donor age affects graft prognosis only when combined with an SFSG. Ikegami et al. (65) reported that the function and regeneration of the allografts from older donors in LDLT are worse than those of their younger counterparts. Tanemura et al. also (66) reported that donor age ( $\geq 50$ years) was 
independently correlated with impaired remnant liver regeneration at 6 months in right

lobe LDLT.

d. Congestion

The magnitude of the impact of tissue congestion caused by interrupted venous drainage is highly variable among grafts. Severe congestion in the anterior segment has been reported to occur in right lobe grafts without the middle hepatic vein, which leads to massive ascites and graft dysfunction (8).

\section{Perioperative recipient related factors}

\section{A. Preoperative recipient status:}

With respect to the maintenance of the initial graft function, the post-transplant metabolic and synthetic demands in recipients with severely damaged liver function (hyperbilirubinemia, coagulopathy) and a pre-operative deteriorated general condition (renal dysfunction, septic state, etc.) aggravate the metabolic function of the graft $(1,67)$. Furthermore, the liver grafts may be insufficiently functional for the excessive metabolic and synthetic demands of high-risk recipients, including their reduced metabolic and synthetic capacities. Therefore, a pre-operative deteriorated condition with a high model 
for endstage liver disease (MELD) score may impair the function of the graft, leading to graft dysfunction, graft failure and eventually multiple organ failure, especially in SFSG.

Yoshizumi et al. (68) reported that a larger graft is necessary if the donor age is $>50$ years and the MELD score is $>20$. Accordingly, Ikegami et al. (69) recommended that high-risk patients should receive a larger, younger graft to minimize the risk of SFSS.

\section{B. Portal circulation (Pressure and Flow):}

After LDLT, Ogura et al. (70) demonstrated that a PVP $<15 \mathrm{mmHg}$ is associated with good patient outcome in a retrospective clinical analysis: patients with a PVP $<15 \mathrm{mmHg}$ demonstrated a better 2-year survival (93.0\%) than patients with a portal pressure $\geq 15$ $\mathrm{mmHg}(66.3 \%)$.

Hessheimer et al. (58) reported that the PV-inferior vena cava (IVC) pressure gradient and PVP were significantly higher in SFSG liver transplantation in swine and that the PCS decreased both the PVP and PV-IVC pressure gradients. However, Ogura et al. (12) reported in a retrospective clinical study of LDLT that although the PV-IVC pressure gradient was higher in the group with the higher PVP, there were no significant differences in the 1- and 3-year survival rates when they divided and analyzed their study 
group by low $(<9 \mathrm{~mm} \mathrm{Hg})$ and high $(\geq 9 \mathrm{~mm} \mathrm{Hg})$ PV-IVC pressure gradients. Further experiments or clinical trials of SFSG are necessary to determine whether the PVP or PV-IVC pressure gradient is more significant for SFSG.

In clinical research, we showed that a high compliance (PVF/PVP) graft in which the PVF can be maintained at a high level despite a low PVP is a good graft for postoperative liver graft function (71). The optimal portal venous circulation for the liver graft could depend on the graft size and quality.

\section{Intervention to avoid SFSS}

\section{(1) Graft selection: increase the graft volume and maximize the outflow}

After the concept of "SFSS" had been reported, the graft type shifted from the left side to the right side of the liver to increase the liver graft volume. Dual graft liver transplantation was also proposed when two donors were available in some institutes $(72$, 73).

Regarding the usage of a "right-side graft", to avoid the development of a congested area in the anterior segment, some institutes have preferred to use a "with MHV graft". Fan et al. chose an extended right-lobe graft with the MHV (74). In contrast, the additional 
venous reconstruction of the anterior segment with an interposition vein graft has been adopted by Lee et al. (8). The reconstruction of the segment V and VIII branches using jump grafts has been reported (75). In our institute, we have performed the venous reconstruction of the anterior segment together with an anterior patch plasty of the hepatic vein using the native portal vein to maximize the liver graft outflow (76).

We reported that the compliance per unit of graft weight in left-lobe grafts is higher than in right lobe grafts without MHV in LDLT (71). Shimada et al. (77) also reported that left-lobe grafts are a feasible option for LDLT because the outflow of the left-lobe graft is considered superior to that of the right-lobe graft and in the case of right-lobe grafts without the MHV, hepatic venous drainage is one of the most critical problems. Accordingly, beginning in December 2007, our institution has actively selected the left-lobe graft for use in LDLT to maximize the graft outflow and minimize the risks to the healthy donor.

\section{(2) Portal inflow modulation}

Boilot et al. (78) first reported a case in which a recipient-transplanted SFSG with a

GRWR of $0.61 \%$ was successfully treated by the reduction of PVP with a mesocaval 
shunt. Thereafter, several surgeons have reported the successful treatment of SFSG by surgical manipulations to reduce the PVP and PVF with a splenic arterial ligation (28), PCS $(27,79,80)$ or splenectomy $(12,81-83)$ in clinical and animal studies $(84,85)$.

However, because the diversion of portal inflow can lead to liver necrosis or atrophy, an adequate PVF is essential for liver regeneration $(26,52,58)$. We reported that an SFSG-transplanted swine with a large PCS could not survive more than 5 days after liver transplantation, with its autopsy showing massive hepatic necrosis. A large PCS, which would greatly reduce the PVF and therefore result in graft failure, should be avoided (26). Therefore, in our institution, a splenectomy is performed first to decrease the PVP $(<15$ $\mathrm{mmHg}$ ), and all large collaterals are ligated to prevent the steal phenomenon in some situations, which decrease the compliance after LDLT (such as rejection) (83).

\section{(3) Other interventions}

In experimental research, several pharmacological interventions have been reported to improve the survival after SFSG, including the portal infusion of prostaglandin E1 (86), granulocyte colony-stimulating factor (87), endothelin A receptor antagonist (31), redox factor-1 (88), somatostatin (89), and hyperbaric oxygen treatment (90) to promote liver 
regeneration or reduce ischemia-reperfusion injury after an SFSG liver transplantation.

\section{(4) Organ preservation}

Newly developed preservation solutions, such as POLYSOL (32), activated protein C

(91) in preservation solution, and cold preservation using retrograde nitric oxide with oxygen administration, for SFSG liver transplantation (92) were reported to recondition the liver graft viability and promote liver regeneration in rats.

\section{Conclusion}

SFSG has become an issue again with respect to pursuing donor safety. Because the occurrence of SFSS is determined by not only the liver graft volume but also a combination of multiple negative factors, we should manage all risk factors and make efforts to improve the outcomes associated with SFSG. 


\section{References}

1. Kiuchi T, Kasahara M, Uryuhara K, Inomata Y, Uemoto S, Asonuma K, et al.

Impact of graft size mismatching on graft prognosis in liver transplantation from

living donors. Transplantation. 1999;67:321-327.

2. Ikegami T, Shimada M, Imura S, Arakawa Y, Nii A, Morine Y, et al. Current concept of small-for-size grafts in living donor liver transplantation. Surg Today. 2008;38:971-982.

3. Dahm F, Georgiev P, Clavien PA. Small-for-size syndrome after partial liver transplantation: definition, mechanisms of disease and clinical implications. Am J Transplant. 2005;5:2605-2610.

4. Fan ST, Lo CM, Liu CL, Wang WX, Wong J, Peitgen HO, et al. Safety and necessity of including the middle hepatic vein in the right lobe graft in adult-to-adult live donor liver transplantation. Ann Surg. 2003;238:137-148.

5. Kasahara M, Takada Y, Fujimoto Y, Ogura Y, Ogawa K, Uryuhara K, et al. Impact of right lobe with middle hepatic vein graft in living-donor liver transplantation. 2005;5:1339-1346. 
6. Asakuma M, Fujimoto Y, Bourquain H, Uryuhara K, Hayashi M, Tanigawa N.

Graft selection algorithm based on congestion volume for adult living donor liver transplantation. 2007;7:1788-1796.

7. Yu Y, Lv L, Qian X, Chen N, Yao A, Pu LY, et al. Anti-fibrotic Effect of Hepatocyte Growth Factor-expressing Mesenchymal Stem Cells in Small-for-size Liver Transplant Rats. Stem Cells Dev. 2009.

8. Lee S, Park K, Hwang S, Lee Y, Choi D, Kim K, et al. Congestion of right liver graft in living donor liver transplantation. Transplantation. 2001;71:812-814.

9. Ito T, Kiuchi T, Yamamoto H, Maetani Y, Oike F, Kaihara S, et al. Efficacy of anterior segment drainage reconstruction in right-lobe liver grafts from living donors. Transplantation. 2004;77:865-868.

10. Shirouzu Y, Ohya Y, Suda H, Asonuma K, Inomata Y. Massive ascites after living donor liver transplantation with a right lobe graft larger than $0.8 \%$ of the recipient's body weight. Clin Transplant. 2010;24:520-527.

11. Kaido T, Mori A, Ogura Y, Hata K, Yoshizawa A, Iida T, et al. Lower limit of the graft-to-recipient weight ratio can be safely reduced to $0.6 \%$ in adult-to-adult 
living donor liver transplantation in combination with portal pressure control.

Transplantation proceedings. 2011;43:2391-2393.

12. Ogura Y, Hori T, El Moghazy WM, Yoshizawa A, Oike F, Mori A, et al. Portal pressure $<15 \mathrm{~mm} \mathrm{Hg}$ is a key for successful adult living donor liver transplantation utilizing smaller grafts than before. Liver transplantation : official publication of the American Association for the Study of Liver Diseases and the International Liver Transplantation Society. 2010;16:718-728.

13. Sugawara Y, Makuuchi M, Takayama T, Imamura H, Dowaki S, Mizuta K, et al. Small-for-size grafts in living-related liver transplantation. J Am Coll Surg. 2001;192:510-513.

14. Selzner M, Kashfi A, Cattral MS, Selzner N, Greig PD, Lilly L, et al. A graft to body weight ratio less than 0.8 does not exclude adult-to-adult right-lobe living donor liver transplantation. Liver transplantation : official publication of the American Association for the Study of Liver Diseases and the International Liver Transplantation Society. 2009;15:1776-1782.

15. Tucker ON, Heaton N. The 'small for size' liver syndrome. Curr Opin Crit Care. 
$2005 ; 11: 150-155$.

16. Soejima Y, Taketomi A, Yoshizumi T, Uchiyama H, Harada N, Ijichi H, et al.

Feasibility of left lobe living donor liver transplantation between adults: an 8-year, single-center experience of 107 cases. Am J Transplant. 2006;6:1004-1011.

17. Hill MJ, Hughes M, Jie T, Cohen M, Lake J, Payne WD, et al. Graft weight/recipient weight ratio: how well does it predict outcome after partial liver transplants? Liver transplantation : official publication of the American Association for the Study of Liver Diseases and the International Liver Transplantation Society. 2009;15:1056-1062.

18. Ikegami T, Shirabe K, Yoshizumi T, Aishima S, Taketomi YA, Soejima Y, et al. Primary graft dysfunction after living donor liver transplantation is characterized by delayed functional hyperbilirubinemia. Am J Transplant. 2012;12:1886-1897.

19. Ferrero A, Vigano L, Polastri R, Muratore A, Eminefendic H, Regge D, et al. Postoperative liver dysfunction and future remnant liver: where is the limit? Results of a prospective study. World J Surg. 2007;31:1643-1651.

20. Schindl MJ, Redhead DN, Fearon KC, Garden OJ, Wigmore SJ. The value of 
residual liver volume as a predictor of hepatic dysfunction and infection after major liver resection. Gut. 2005;54:289-296.

21. Vauthey JN, Chaoui A, Do KA, Bilimoria MM, Fenstermacher MJ, Charnsangavej C, et al. Standardized measurement of the future liver remnant prior to extended liver resection: methodology and clinical associations. Surgery. 2000;127:512-519.

22. Demetris AJ, Kelly DM, Eghtesad B, Fontes P, Wallis Marsh J, Tom K, et al. Pathophysiologic observations and histopathologic recognition of the portal hyperperfusion or small-for-size syndrome. Am J Surg Pathol. 2006;30:986-993.

23. Man K, Lo CM, Ng IO, Wong YC, Qin LF, Fan ST, et al. Liver transplantation in rats using small-for-size grafts: a study of hemodynamic and morphological changes. Arch Surg. 2001;136:280-285.

24. Fondevila C, Hessheimer AJ, Taura P, Sanchez O, Calatayud D, de Riva N, et al. Portal hyperperfusion: mechanism of injury and stimulus for regeneration in porcine small-for-size transplantation. Liver transplantation : official publication of the American Association for the Study of Liver Diseases and the International 
Liver Transplantation Society. 2010;16:364-374.

25. Asakura T, Ohkohchi N, Orii T, Koyamada N, Tsukamoto S, Sato M, et al. Portal vein pressure is the key for successful liver transplantation of an extremely small graft in the pig model. Transpl Int. 2003;16:376-382.

26. Yagi S, Iida T, Hori T, Taniguchi K, Nagahama M, Isaji S, et al. Effect of portal haemodynamics on liver graft and intestinal mucosa after small-for-size liver transplantation in swine. Eur Surg Res. 2012;48:163-170.

27. Troisi R, Cammu G, Militerno G, De Baerdemaeker L, Decruyenaere J, Hoste E, et al. Modulation of portal graft inflow: a necessity in adult living-donor liver transplantation? Ann Surg. 2003;237:429-436.

28. Ito T, Kiuchi T, Yamamoto H, Oike F, Ogura Y, Fujimoto Y, et al. Changes in portal venous pressure in the early phase after living donor liver transplantation: pathogenesis and clinical implications. Transplantation. 2003;75:1313-1317.

29. Hori T, Yagi S, Iida T, Taniguchi K, Yamagiwa K, Yamamoto C, et al. Stability of cirrhotic systemic hemodynamics ensures sufficient splanchnic blood flow after living-donor liver transplantation in adult recipients with liver cirrhosis. World $\mathbf{J}$ 
Gastroenterol. 2007;13:5918-5925.

30. Liang TB, Man K, Kin-Wah Lee T, Hong-Teng Tsui S, Lo CM, Xu X, et al.

Distinct intragraft response pattern in relation to graft size in liver transplantation.

Transplantation. 2003;75:673-678.

31. Palmes D, Minin E, Budny T, Uhlmann D, Armann B, Stratmann U, et al. The endothelin/nitric oxide balance determines small-for-size liver injury after reduced-size rat liver transplantation. Virchows Arch. 2005;447:731-741.

32. Yagi S, Doorschodt BM, Afify M, Klinge U, Kobayashi E, Uemoto S, et al. Improved preservation and microcirculation with POLYSOL after partial liver transplantation in rats. J Surg Res. 2011;167:e375-383.

33. Smyrniotis V, Kostopanagiotou G, Kondi A, Gamaletsos E, Theodoraki K, Kehagias D, et al. Hemodynamic interaction between portal vein and hepatic artery flow in small-for-size split liver transplantation. Transpl Int. 2002;15:355-360.

34. Hashimoto N, Ohyanagi H. Effect of acute portal hypertension on gut mucosa. Hepatogastroenterology. 2002;49:1567-1570. 
35. Quigley M. Bacterial translocation in acute and chronic portal hypertension. Hepatology. 1994;20:264-266.

36. Wang XD, Guo WD, Wang Q, Andersson R, Ekblad E, Soltesz V, et al. The association between enteric bacterial overgrowth and gastrointestinal motility after subtotal liver resection or portal vein obstruction in rats. Eur J Surg. 1994;160:153-160.

37. Wang X, Andersson R, Soltesz V, Wang L, Bengmark S. Effect of portal hypertension on bacterial translocation induced by major liver resection in rats.

Eur J Surg. 1993;159:343-350.

38. Garcia-Tsao G, Albillos A, Barden GE, West AB. Bacterial translocation in acute and chronic portal hypertension. Hepatology. 1993;17:1081-1085.

39. Yao GX, Shen ZY, Xue XB, Yang Z. Intestinal permeability in rats with CCl4-induced portal hypertension. World J Gastroenterol. 2006;12:479-481.

40. Kiuchi T, Tanaka K, Ito T, Oike F, Ogura Y, Fujimoto Y, et al. Small-for-size graft in living donor liver transplantation: how far should we go? Liver Transpl. 2003;9:S29-35. 
41. Nakamura T, Nishizawa T, Hagiya M, Seki T, Shimonishi M, Sugimura A, et al.

Molecular cloning and expression of human hepatocyte growth factor. Nature.

$1989 ; 342: 440-443$

42. Kan M, Huang JS, Mansson PE, Yasumitsu H, Carr B, McKeehan WL.

Heparin-binding growth factor type 1 (acidic fibroblast growth factor): a potential biphasic autocrine and paracrine regulator of hepatocyte regeneration. Proc Natl Acad Sci U S A. 1989;86:7432-7436.

43. McGowan JA, Strain AJ, Bucher NL. DNA synthesis in primary cultures of adult rat hepatocytes in a defined medium: effects of epidermal growth factor, insulin, glucagon, and cyclic-AMP. J Cell Physiol. 1981;108:353-363.

44. Miyazawa K, Shimomura T, Kitamura A, Kondo J, Morimoto Y, Kitamura N. Molecular cloning and sequence analysis of the cDNA for a human serine protease reponsible for activation of hepatocyte growth factor. Structural similarity of the protease precursor to blood coagulation factor XII. J Biol Chem. 1993;268:10024-10028.

45. Mochida S, Ishikawa K, Inao M, Shibuya M, Fujiwara K. Increased expressions 
of vascular endothelial growth factor and its receptors, flt-1 and KDR/flk-1, in regenerating rat liver. Biochem Biophys Res Commun. 1996;226:176-179.

46. Marubashi S, Sakon M, Nagano H, Gotoh K, Hashimoto K, Kubota M, et al. Effect of portal hemodynamics on liver regeneration studied in a novel portohepatic shunt rat model. Surgery. 2004;136:1028-1037.

47. Yagi S, Iida T, Taniguchi K, Hori T, Hamada T, Fujii K, et al. Impact of portal venous pressure on regeneration and graft damage after living-donor liver transplantation. Liver transplantation : official publication of the American Association for the Study of Liver Diseases and the International Liver Transplantation Society. 2005;11:68-75.

48. Oura T, Taniguchi M, Shimamura T, Suzuki T, Yamashita K, Uno M, et al. Does the permanent portacaval shunt for a small-for-size graft in a living donor liver transplantation do more harm than good? Am J Transplant. 2008;8:250-252.

49. Ninomiya M, Harada N, Shiotani S, Hiroshige S, Minagawa R, Soejima Y, et al. Hepatocyte growth factor and transforming growth factor betal contribute to regeneration of small-for-size liver graft immediately after transplantation. 
Transpl Int. 2003;16:814-819.

50. Guest J, Ryan CJ, Benjamin IS, Blumgart LH. Portacaval transposition and subsequent partial hepatectomy in the rat: effects on liver atrophy, hypertrophy and regenerative hyperplasia. Br J Exp Pathol. 1977;58:140-146.

51. Kahn D, Kajani M, Zeng Q, Lai HS, Eagon PK, Makowka L, et al. Effect of partial portal vein ligation on hepatic regeneration. J Invest Surg. 1988;1:267-276.

52. Kawasaki T, Moriyasu F, Kimura T, Someda H, Fukuda Y, Ozawa K. Changes in portal blood flow consequent to partial hepatectomy: Doppler estimation. Radiology. 1991;180:373-377.

53. Kin Y, Nimura Y, Hayakawa N, Kamiya J, Kondo S, Nagino M, et al. Doppler analysis of hepatic blood flow predicts liver dysfunction after major hepatectomy. World J Surg. 1994;18:143-149.

54. Sato Y, Koyama S, Tsukada K, Hatakeyama K. Acute portal hypertension reflecting shear stress as a trigger of liver regeneration following partial hepatectomy. Surg Today. 1997;27:518-526.

55. Kato Y, Shimazu M, Wakabayashi G, Tanabe M, Morikawa Y, Hoshino K, et al. 
Significance of portal venous flow in graft regeneration after living related liver transplantation. Transplant Proc. 2001;33:1484-1485.

56. Schoen JM, Wang HH, Minuk GY, Lautt WW. Shear stress-induced nitric oxide release triggers the liver regeneration cascade. Nitric Oxide. 2001;5:453-464.

57. Eguchi S, Yanaga K, Sugiyama N, Okudaira S, Furui J, Kanematsu T. Relationship between portal venous flow and liver regeneration in patients after living donor right-lobe liver transplantation. Liver Transpl. 2003;9:547-551.

58. Hessheimer AJ, Fondevila C, Taura P, Munoz J, Sanchez O, Fuster J, et al. Decompression of the portal bed and twice-baseline portal inflow are necessary for the functional recovery of a "small-for-size" graft. Annals of surgery. 2011;253:1201-1210.

59. Selzner M, Camargo CA, Clavien PA. Ischemia impairs liver regeneration after major tissue loss in rodents: protective effects of interleukin-6. Hepatology. 1999;30:469-475.

60. Selzner N, Selzner M, Tian Y, Kadry Z, Clavien PA. Cold ischemia decreases liver regeneration after partial liver transplantation in the rat: A 
TNF-alpha/IL-6-dependent mechanism. Hepatology. 2002;36:812-818.

61. Minor T, Akbar S, Tolba R, Dombrowski F. Cold preservation of fatty liver grafts:

prevention of functional and ultrastructural impairments by venous oxygen persufflation. J Hepatol. 2000;32:105-111.

62. Bahde R, Spiegel HU. Hepatic ischaemia-reperfusion injury from bench to bedside. Br J Surg. 2010;97:1461-1475.

63. Hayashi M, Fujii K, Kiuchi T, Uryuhara K, Kasahara M, Takatsuki M, et al. Effects of fatty infiltration of the graft on the outcome of living-related liver transplantation. Transplantation proceedings. 1999;31:403.

64. Moon JI, Kwon CH, Joh JW, Jung GO, Choi GS, Park JB, et al. Safety of small-for-size grafts in adult-to-adult living donor liver transplantation using the right lobe. Liver transplantation : official publication of the American Association for the Study of Liver Diseases and the International Liver Transplantation Society. 2010;16:864-869.

65. Ikegami T, Nishizaki T, Yanaga K, Shimada M, Kishikawa K, Nomoto K, et al. The impact of donor age on living donor liver transplantation. Transplantation. 
2000;70:1703-1707.

66. Tanemura A, Mizuno S, Wada H, Yamada T, Nobori T, Isaji S. Donor age affects liver regeneration during early period in the graft liver and late period in the remnant liver after living donor liver transplantation. World $\mathbf{J}$ Surg. 2012;36:1102-1111.

67. Uemoto S, Inomata Y, Sakurai T, Egawa H, Fujita S, Kiuchi T, et al. Living donor liver transplantation for fulminant hepatic failure. Transplantation. 2000;70:152-157.

68. Yoshizumi T, Taketomi A, Soejima Y, Uchiyama H, Ikegami T, Harada N, et al. Impact of donor age and recipient status on left-lobe graft for living donor adult liver transplantation. Transplant international : official journal of the European Society for Organ Transplantation. 2008;21:81-88.

69. Ikegami T, Shimada M, Imura S, Arakawa Y, Nii A, Morine Y, et al. Current concept of small-for-size grafts in living donor liver transplantation. Surgery today. 2008;38:971-982.

70. Yagi S, Iida T, Taniguchi K, Hori T, Hamada T, Fujii K, et al. Impact of portal 
venous pressure on regeneration and graft damage after living-donor liver transplantation. Liver Transpl. 2005;11:68-75.

71. Yagi S, Iida T, Hori T, Taniguchi K, Yamamoto C, Yamagiwa K, et al. Optimal portal venous circulation for liver graft function after living-donor liver transplantation. Transplantation. 2006;81:373-378.

72. Lee S, Hwang S, Park K, Lee Y, Choi D, Ahn C, et al. An adult-to-adult living donor liver transplant using dual left lobe grafts. Surgery. 2001;129:647-650.

73. Kaihara S, Ogura Y, Kasahara M, Oike F, You Y, Tanaka K. A case of adult-to-adult living donor liver transplantation using right and left lateral lobe grafts from 2 donors. Surgery. 2002;131:682-684.

74. Fan ST, Lo CM, Liu CL. Technical refinement in adult-to-adult living donor liver transplantation using right lobe graft. Annals of surgery. 2000;231:126-131.

75. Sano K, Makuuchi M, Miki K, Maema A, Sugawara Y, Imamura H, et al. Evaluation of hepatic venous congestion: proposed indication criteria for hepatic vein reconstruction. Annals of surgery. 2002;236:241-247.

76. Mori A, Kaido T, Ogura Y, Ogawa K, Hata K, Yagi S, et al. Standard hepatic vein 
reconstruction with patch plasty using the native portal vein in adult living donor liver transplantation. Liver transplantation : official publication of the American Association for the Study of Liver Diseases and the International Liver Transplantation Society. 2012;18:602-607.

77. Shimada M, Shiotani S, Ninomiya M, Terashi T, Hiroshige S, Minagawa R, et al. Characteristics of liver grafts in living-donor adult liver transplantation: comparison between right- and left-lobe grafts. Arch Surg. 2002;137:1174-1179.

78. Boillot O, Delafosse B, Mechet I, Boucaud C, Pouyet M. Small-for-size partial liver graft in an adult recipient; a new transplant technique. Lancet. 2002;359:406-407.

79. Takada Y, Ueda M, Ishikawa Y, Fujimoto Y, Miyauchi H, Ogura Y, et al. End-to-side portocaval shunting for a small-for-size graft in living donor liver transplantation. Liver Transpl. 2004;10:807-810.

80. Yamada T, Tanaka K, Uryuhara K, Ito K, Takada Y, Uemoto S. Selective hemi-portocaval shunt based on portal vein pressure for small-for-size graft in adult living donor liver transplantation. Am J Transplant. 2008;8:847-853. 
81. Shimada M, Ijichi H, Yonemura Y, Harada N, Shiotani S, Ninomiya M, et al. The impact of splenectomy or splenic artery ligation on the outcome of a living donor adult liver transplantation using a left lobe graft. Hepatogastroenterology. 2004;51:625-629.

82. Kuriyama N, Isaji S, Kishiwada M, Ohsawa I, Hamada T, Mizuno S, et al. Dual cytoprotective effects of splenectomy for small-for-size liver transplantation in rats. Liver transplantation : official publication of the American Association for the Study of Liver Diseases and the International Liver Transplantation Society. 2012.

83. Hori T, Ogura Y, Ogawa K, Kaido T, Segawa H, Okajima H, et al. How transplant surgeons can overcome the inevitable insufficiency of allograft size during adult living-donor liver transplantation: strategy for donor safety with a smaller-size graft and excellent recipient results. Clin Transplant. 2012;26:E324-334.

84. Boillot O, Mechet I, Le Derf Y, Bernard P, Figueiredo P, Berger F, et al. Portomesenteric disconnection for small-for-size grafts in liver transplantation: Preclinical studies in pigs. Liver Transpl. 2003;9:S42-46. 
85. Pouyet M, Paquet C. Effect of mesocaval shunt on survival of small-for-size liver grafts. Transplantation. 2004;77:952; author reply 952.

86. Suehiro T, Shimada M, Kishikawa K, Shimura T, Soejima Y, Yoshizumi T, et al.

Effect of intraportal infusion to improve small for size graft injury in living donor adult liver transplantation. Transplant international : official journal of the European Society for Organ Transplantation. 2005;18:923-928.

87. Ji Y, Dahmen U, Madrahimov N, Madrahimova F, Xing W, Dirsch O. G-CSF administration in a small-for-size liver model. J Invest Surg. 2009;22:167-177.

88. Guo L, Haga S, Enosawa S, Naruse K, Harihara Y, Sugawara Y, et al. Improved hepatic regeneration with reduced injury by redox factor-1 in a rat small-sized liver transplant model. Am J Transplant. 2004;4:879-887.

89. Xu X, Man K, Zheng SS, Liang TB, Lee TK, Ng KT, et al. Attenuation of acute phase shear stress by somatostatin improves small-for-size liver graft survival. Liver transplantation : official publication of the American Association for the Study of Liver Diseases and the International Liver Transplantation Society. 2006;12:621-627. 
90. Ijichi H, Taketomi A, Yoshizumi T, Uchiyama H, Yonemura Y, Soejima Y, et al.

Hyperbaric oxygen induces vascular endothelial growth factor and reduces liver injury in regenerating rat liver after partial hepatectomy. $\mathbf{J}$ Hepatol. 2006;45:28-34.

91. Kuriyama N, Isaji S, Hamada T, Kishiwada M, Ohsawa I, Usui M, et al. The cytoprotective effects of addition of activated protein $\mathrm{C}$ into preservation solution on small-for-size grafts in rats. Liver transplantation : official publication of the American Association for the Study of Liver Diseases and the International Liver Transplantation Society. 2010;16:1-11.

92. Yagi S, Nagai K, Srinivasan P, Afify M, Uemoto S, Tolba RH. A Novel Organ-Preservation for Small Partial Liver Transplantations in Rats: Venous Systemic Oxygen Persufflation with Nitric Oxide Gas. Am J Transplant.Inpress. 
Table 1: Proposed definitions of small-for-size syndrome

\begin{tabular}{|c|c|}
\hline & Definition \\
\hline Dahm et al. ${ }^{3)}, 2005$ & $\begin{array}{l}\text { Small-for-size dysfunction (SFSD) } \\
\text { Dysfunction* of a 'small' partial liver graft (GRWR }<0.8 \% \text { ) during the } \\
\text { first postoperative week after the exclusion of other causes } \\
\text { Small-for-size non-function (SFSNF) } \\
\text { Failure } \\
\text { postoperative week after the exclusion of other causes }\end{array}$ \\
\hline Soejima et al. ${ }^{16)}, 2006$ & $\begin{array}{l}\text { Small for size syndrome } \\
\text { Prolonged cholestatis (T.Bil }>10 \mathrm{mg} / \mathrm{dL} \text { on POD14) and intractable } \\
\text { ascites (ascites }>1 \mathrm{~L} \text { on POD } 14 \mathrm{or}>0.5 \mathrm{~L} \text { on POD } 28 \text { ). }\end{array}$ \\
\hline Hill et al. ${ }^{17)}, 2009$ & $\begin{array}{l}\text { Small for size syndrome } \\
\text { T.Bil }>10 \mathrm{mg} / \mathrm{dL} \text { (and continuing to increase) after POD 7, PT-INR >1.5 } \\
\text { and ascites }>2 \mathrm{~L} \text {, excluding mechanical/technical problems. }\end{array}$ \\
\hline Ikegami et al. $^{18)}, 2012$ & $\begin{array}{l}\text { Delayed functional hyperbilirubinemia (DFH) } \\
\text { with T.Bil }>20 \mathrm{mg} / \mathrm{dL} \\
\text { For >seven consecutive days after POD 7, excluding technical, } \\
\text { immunological and hepatitis factors. }\end{array}$ \\
\hline
\end{tabular}

* Graft dysfunction $=$ the presence of two of the following on three consecutive days:

bilirubin $>100$ lmol/l, INR > 2, encephalopathy grade 3 or 4 .

* * Graft failure $=$ re-transplantation or death of recipient.

*** Exclusion criteria: technical (e.g. arterial or portal occlusion, outflow congestion, bile leak), immunological (e.g. rejection), infectious (e.g. cholangitis, sepsis). 